\title{
BULK AND MINERAL CHEMISTRY OF THE OLIVINE LEUCITITE FROM JUANA VAZ, SACRAMENTO, MINAS GERAIS, BRAZIL.
}

\author{
José Caruso Moresco Danni ${ }^{(1)}$; Nilson Francisquini Botelho ${ }^{(1)}$; João H. Grossi Sad ${ }^{(2)}$. \\ (1)Depto. Mineral and Petrol. - Univ. Brasília; (2) Inst. Geoc., Univ. Fed. Minas Gerais.
}

The olivine leucitite from Juana Vaz, Sacramento, Minas Gerais state, Brazil, is the first occurence of leucitite bearing volcanic rock recognized in continental Brazil (Murta, 1965, 1966; Guimarães, 1966). The occurence was discovered during a prospection program for bentonitic clay. It is $10 c$ ated $40 \mathrm{~km}$ southeastern of the town of Sacramento, at the border of a plateau namea "Chapadão dos Bugres."

The rock occur on a deep clayey soil (up to 60 meters) originated by weathering of tuffs and pyroclastic breccias of the Mata da Corda formation. The rock occurence may represent a lava flow unit situated at the base of pyroclastic rocks.

The olivine leucitite is black, aphanitic, and presents a microprophiritic texture. It is essentially composed by olivine ( $33 \%$ in volume), leuclite $(20,4 \%)$, diopside $(24,1 \%)$, phlogopite $(7,0 \%)$, magnetite + ilmenite $(9,7 \%)$, perowskite $(1,7 \%)$, apatite $(1,0 \%)$, and interstitial glass $(3,1 \%)$.

Diopside forms prismatic crystal arranged around sub-circulars crystals of leucite $(0.2 \mathrm{~mm})$, which shows multiple complex twins. llmenite, magnetite and perowskite have tendence to form skeletal crystals $(0,1-0,05 \mathrm{~mm})$. The interstitial glass is brown in collor and have aciculars inclusiuns. (apatite?).

The crystallization order is: olivine, leucite, diopside, apatite + oxyous + perowskite, phlogopite, and glass. This is in agreement with the sequence of crystalization experimentally obtained by Foley, (1985) to pelpotassic liquias (Iamproitic) on low foz condition (MW buffer).

olivine xenocrystal are zoned with $M g$ richer cores ( $M g / M g+F e=0,90$ ) than borders $(0,86)$. Euhedral and corroded phenocrysts present very constant $M g / M g+F e$ ratios $(0,86)$, and relatively high values of CaO $(0,4$ to 0,6 wt\%). Clinopyroxenes have very constant $\mathrm{Mg}: \mathrm{Fe}: \mathrm{Ca}$ ratios corresponding to dlopside with $\mathrm{Mg} / \mathrm{Mg}+\mathrm{Fe}=0.89$. Characteristicaly they are $S i$ and $A l$ deficient, needing $\mathrm{Fe}=3$ to complete the tetrahedric positions. The Tioz content $(2,3$ to 2,6 wt\%) is distinct from diopsides from others uitrapotassic rocks $(0,7$ to 2,4 wt\%) (Barton, 1979; Mitchel, 1985). Their Al and Na contents are closer to clinopyroxenes from the Leuclte Hills rocks than the Toro Ankole diopsldes. Leuclte has a compositon very similar to the laeal formula, except by a little deficlence in silicium $(0,03$ cation/unit), that is compensated by the entry of $\mathrm{Fe}+3$ in tetrahedric site. Contrary to leucltes from Toro Ankole, they are very poor in sodium, i.e. Whithout kalsilite exsolutions. Phiogopites have high contents in $B$ a 0 ( 2,3 to 3,4 wt\%; ) and present $S I$ and $A l$ deficlency $(0,55$ to 0,48 atoms per formula unit). They have compositions similar to the kamafugltic phlogopites and are very distinct from the lamproltic and kimberiltic phlogopites (Mitchell, 1985). In a MgTi03, FeTio3, ana Fez03 plot, the limenites fall in the kimberlitic field and present Mgo values $(8,5 w t \%)$, higher than the lamproltic ones. Apatites are fluor, $B a$, and REE bearing, and present a $P+4$ deficience, due probabiy to a substitution of the type: Ca+P = REE $+5 i$. Perowskite shows high contents of BaO(2,7 - 4, Owt\%), La, Nd, 
and $\operatorname{sm}$ oxydes $(2,5 w t \%)$, and carry 0,9 wt\% of Na己0. The brown interstitial glass is very poor in SiOd, Na, and k (leucite depleted), rich in Al and probably HzO. Fe, Mg and Ti are relatively concentrated in it. A CIPW norm composition results in ollvine, hyperstene, ortoclase, anorthite and corindon. This leucitite is an ultrabasic (sioz - 40wt\%), perpotassic $(\mathrm{K} 20 / \mathrm{NaCO}\rangle \mathrm{C}, 5)$, sub-aluminous rock, with MgO/MgO+FeO (moleculas proportion) of 75. It presents simultaneousiy high concentration in transitions elements ( $T i, N i, G r, G O$ ) and in LIL elements (K, Ro, Ba, $S r, N b, Z r)$. These features, common to others kamafugitic rocks, are characteristic of primary liquids, probably derived from low grade partial fusion of an enriched peridotitic mantle with phlogopite and K-richterite, (Foley et al., 1987). In view of the above features and due to the abundance of olivine leucitites in the volcanic pile of the Mata da corda Formation (seer and Moraes, 1988), this rock can represent one of the primary magmas that originated the volkanic alkaline Alto Paranaiba province.

\section{Rock chemlstry ( 1 and 2$)$, CIPW norm and InterstitIal glass composition (3)}

\begin{tabular}{|c|c|c|c|c|c|c|c|c|}
\hline Oxides & 1 & 2 & 3 & & $1 p p m$ & & 1 & 2 \\
\hline S102 & 40.89 & 39.37 & 37.25 & $\mathrm{Sc}$ & 17.1 & or & 7.4 & - \\
\hline T।OD & 4.08 & 4.20 & 2. 90 & V & - 208 & an & - & 3.5 \\
\hline A1203 & 4.56 & 5.36 & 11.50 & $\mathrm{Cr}$ & -1366 & $1 e$ & 6.9 & 12.5 \\
\hline FeOT & 12.69 & 12.38 & 10.58 & Co & -69 & ne & 4.4 & 3.2 \\
\hline MnO & 0.16 & 0.37 & 0.07 & $\mathrm{Ni}$ & -1034 & di & 19.4 & 11.9 \\
\hline $\mathrm{MgO}$ & 22.23 & 25.70 & 20.27 & $P B$ & 8.7 & ho & 5.2 & 2. 7 \\
\hline $\mathrm{CaO}$ & 7.01 & 6.55 & 0.76 & Th & 9.4 & fo & 32.5 & 41.0 \\
\hline $\mathrm{BaO}$ & 0.12 & - & - & $\mathrm{Ga}$ & 12.2 & $f a$ & 10.9 & 11.6 \\
\hline Sro & 0.12 & - & - & $s r$ & -944 & cs & - & 2. 2 \\
\hline $\mathrm{NaCO}$ & 1.01 & 0.71 & 0.19 & $\mathrm{Ba}$ & -1481 & il & 7.7 & 8.0 \\
\hline KटO & 2. 74 & 2. 70 & 2. 45 & $\mathrm{Rb}$ & -167 & $a p$ & 1.7 & 1.3 \\
\hline Pट05 & 0.70 & 0.56 & - & Nb & 77 & DI & 18.7 & 15.7 \\
\hline LOO & 1.93 & ㄹ. 10 & $13.8 *$ & $\mathrm{Zr}$ & -384 & & & \\
\hline \multirow[t]{4}{*}{ TOT } & 98.22 & 98.00 & 100.00 & $\mathrm{Ce}$ & $\begin{array}{l}-\quad 97 \\
\end{array}$ & & & \\
\hline & & & & $Y$ & 17.2 & & & \\
\hline & & & & $Y b$ & 2. 55 & & & \\
\hline & & & & La & 88 & & & \\
\hline
\end{tabular}

(2) after Murta, 1966. * Galculated by difference.

\section{Bibllography}

Barton, M., 1979 - A comparative study of some minerals occuring in the potassium-rich alkaline rocks of the leucite Hils, Wyomming, the vico volcano, Western italy, and the Toro Ankole reglon, Uganda, N.Jb. Min. Abh. 137. 113-134.

Foley, S.F., 1985 - The oxidation state of Lamproitic Magmas, IMPM Tschermaks Min. Petr. Mitt. 34, 217-238.

Foley, S.F., Venturelli, G., Green, D.H., Toscani L., 1987- The ultrapotassic rocks: characteristics, classifications, and contrants for Petrogenetic models, Earth Sci. Rev. 24, 81134.

Guimarães, D. 1966 - Idade do Ugandito de Sacramento, M.G., pelo método da birrefringêncla, Bol. Inst. Geol. EFMOP, V.l no. 3,4, 107-159, ouro Preto, MG. 
Ladeira, E.A., Brito, O.E.A., 1968 - Contribuíão à geología do Planalto da Mata da Corda, An. XXIl Cong. Bras. Geol., v.2, p. 181-199, Belo Horizonte, MG.

Mitchell, R.H., 1985 a Review of the mineralogy of lamproites. Trans. Geol. Soc. Africa, 88, $411-437$.

Murta, L.L.R. 1965 - Nota sobre a rocha leucltitica de Sacramento, Minas Gerais, Rev. Cienc. Cult. V. 17, no. 2, p. 135, São Paulo, SP.

Murta, L.L. R. 1966 - o vulcanito leucititico de Sacramento, Minas Gerais, Bol. Inst. Geol., EFMOP, v. I no. . 13-20, ouro Preto, MG.

Seer, HJ.J., Moraes, L.C., 1988 - Estudo Petrograflco das rochas I gneas alcalinas da reglão de Lagoa Formosa, MG., REv. Bras. Geoc., v. 18, no. 2, 134-140, São Paulo, SP. 